\title{
АДМІНІСТРАТИВНО-ПРАВОВІ ЗАСАДИ ДІЯЛЬНОСТІ НАЦІОНАЛЬНОЇ ПОЛЮІЇ ЩОДО НАДАННЯ ПУБЛІЧНИХ ПОСЛУГ
}

\author{
БУКІН Микола Петрович - кандидат юридичних наук, доцент, завідувач \\ кафедри військової підготовки Національного університету цивільного захисту \\ Україи
}

СТОЛБА Вячеслав Анатолійович - старший викладач кафедри військової підготовки Національного університету цивільного захисту України

DOI:10.32782/LAW.2019.3.10

УДК: 342.95 (477)

У статті розглянуті особливості діяльносmі Національноӥ полічй з надання публічних послуг громадянам України. За допомогою аналізу наукових поглядів сбормовано та надано авторсъке визначення понять «адміністративно-правові засади», «сервісна держава» та «надання публічних послуг» (у контексті діяльності Наиіональної полічї). Встановлено, що, враховуючи специфічний статус підрозділів Начіональної полічій України, надання ними публічних послуг населенню має свої характерні особливості. Надано пропозициї стосовно вдосконалення деяких з адміністративних процедур надання публічних послуг. Особливий акцент зроблено на необхідності удосконалення адміністративно-правового забезпечення професійної діяльності співробітників полічій. Запропоновано внесення змін до пробільного законодавства з метою підвищення ефбективності діяльності внутрішньосистемних підрозділів, щзо входять до складу Національноі полічій України.

Ключові слова: начіональна полічія, публічні послуги, сервісна держава, структурні підрозділи, законодавче забезпечення, правове регулювання, адміністративне право, адміністративний процес, державна система.

Постановка проблеми

Останнім часом серед численних проблем та викликів, що постають наразі перед сучасними державами, які воліють стати успішними або продовжувати підтримувати свій уже досягнутий високий рівень, 3-поміж інших виділяється завдання перетворення певної країни у так звану «сервісну» державу. Головна сутність такої держави повинна полягати у їі спроможності забезпечувати всі необхідні умови для подальшого позитивного зростання економічних, соціальних та правових складових власної життєдіяльності, а також завжди бути спроможною у задоволенні різних законних потреб своїх громадян.

У загальній проблематиці побудови сервісної держави на прикладі України окремо виділяємо специфіку утворення та забезпечення діяльності іï окремих органів виконавчої влади. Зокрема, слід наголосити й на важливості вдалого «сервісного» функціонування правоохоронних підрозділів, у першу чергу, Національної поліції, яка у порівнянні з іншими правоохоронними органами виконує найбільшу кількість правоохоронних завдань. Вагомість успішного запровадження стійкого та повсякденного надання публічних послуг населенню України вітчизняними поліцейськими пояснюється тим, що саме працівникам Національної поліції більше за будь-яку іншу правоохоронну службу доводиться стикатися з громадянами.

Аналіз останніх досліджень і публікацій

Адміністративно-правові засади діяльності Національної поліції щодо надання публічних послуг громадянам України були предметом наукових досліджень: І. В. Арістової, О. М. Бандурки, А. Т. Комзюка, Н. П. Матюхіної, І. М. Пахомова, В. П. Пєткова, О. П. Рябченко, В. П. Тимощука, А. В. Ткаченка, О. І. Остапенка, О. Г. Фролової, А. В. Юрмача 
та інших. Проте, незважаючи на численні дослідження, багато питань, пов'язаних з реалізацією особою права на отримання публічної послуги, залишаються не вирішеними, що не може негативно не позначатися на рівні забезпеченості прав і свобод людини в державі.

Метою статті $є$ розкриття особливостей адміністративно-правових засад діяльності Національної поліції з надання публічних послуг.

\section{Викдад основного матеріалу}

Задля цілковитого оновлення всіх складових суспільної життєдіяльності вітчизняних громадськості та державної системи, а саме їх політичної, економічної й соціальної частин, важливим є спрямування діяльності державних органів на забезпечення реалізації наданих громадян прав, свобод та законних інтересів. Зміцнення та розвиток вищезгаданих компонентів $\epsilon$ обов'язковим напрямком на шляху до перетворення України на правову та демократичну державу зі стійкою системою стримувань і противаг між трьома основними гілками влади. Особливо наголошується на наявності ефективних та дієвих органів виконавчої влади, а також існуванні та функціонуванні в країні незалежної й незаангажованої судової системи. Без двох останніх факторів та за відсутності чіткого законодавчого забезпечення і правового регулювання професійної діяльності службовців нормальне функціонування правоохоронної системи в такій країні стане абсолютно неможливим.

Заради втілення в життя демократичних принципів, необхідних для існування правового суспільства, вкрай важливим $є$ досягнення органами державної влади свого максимального рівня злагодженості та ефективності, а також їх реформування, спрямованого, насамперед, на забезпечення відповідності ïх діяльності сучасним умовам та стандартам функціонування. Внутрішньосистемні підрозділи Національної поліції, будучи невід'ємним компонентом органів виконавчої влади відповідно до чинного законодавства України, зобов'язані належним шляхом реалізовувати свої повноваження щодо захисту охоронюваних прав, свобод та законних інтересів людини і громадянина.
Згідно зі статтею третьою Конституції України [1], в якій йдеться про визнання безпеки та недоторканості життя, здоров'я, честі й гідності людини як найвищої соціальної цінності в українській державі, саме основоположні права та свободи людини є орієнтиром у визначенні змісту та спрямованості діяльності владних інституцій держави. Твердження про те, що найважливішою метою держави мають бути надійні охорона й забезпечення гарантованих вітчизняним законодавством вищенаведених прав і свобод як найвищих суспільних ідеалів та цінностей, потребує від державної влади певних корінних змін. Головним 3 таких змін повинне стати принципово нове, зроблене у дусі сучасності переосмислення ролі державного механізму в суспільстві. Всі суб'єкти суспільних правовідносин повинні віднайти такий спосіб здійснення взаємних відносин між державою та представниками всіх верств вітчизняного суспільства, при якому громадяни отримували 6 від власної держави корисні для них послуги, а сама держава натомість перетворилася для звичайного громадянина на своєрідний сервісний центр з надання різноманітних послуг, які 6 були покликані значною мірою поліпшити повсякденну життєдіяльність осіб.

Походячи від абсолютно доцільного умовиводу про державу як про найвищу форму з-поміж усіх інших сучасних організацій суспільства, варто наголосити на загальнообов'язковому дотриманні моральних принципів і людських цінностей при формуванні та здійсненні державницької діяльності всіма ключовими системними суб'єктами влади. Це є важливою умовою через те, що, лише базуючись на подібних життєвих поглядах, працівники державних установ зможуть перетворити застарілі бюрократичні заклади, за допомогою яких вчиняються різноманітні злочини проти населення, на реально ефективні та потужно діючі органи, які 6, функціонуючи у системі, були 6 головним елементом сервісної держави. Таким чином, формуючи наведені вище тези й твердження у єдине ціле, варто зазначити, що: по-перше, сучасна держава через систему державних органів не тільки керує суспільством, а й надає йому послуги; по-друге, фізичні та юридичні особи повинні бути не прохачами у відносинах 3 ор- 
ганами влади, а споживачами адміністративних послуг [2].

При спробі дати визначення сутності поняття «публічна адміністративна послуга» правознавці дійшли висновку про тлумачення цього визначення з оглядом на сучасні зміни та реформування. Отже, публічні адміністративні послуги, за думкою вчених, є своєрідним різновидом правовідносин, що виникають при здійсненні суб'єктивних прав фізичної або юридичної особи за заявою останньої, під час реалізації державними органами публічно-владної діяльності, маючи за кінцеву мету отримання певного результату. У контексті розгляду специфіки цього питання варто підкреслити, що дефініції «публічної послуги» та «розпорядчої діяльності» (навіть якщо остання спрямована на захист прав, свобод та законних інтересів громадян) мають дещо відмінні одна від одної риси. Зокрема, різниця між ними може полягати в тому, що забезпечення основоположних прав і свобод громадян $є$ не конкретними діями, що час від часу здійснюються державними установами. Навпаки, це є головним загальним принципом існування і життедіяльності державних органів, тому на виконання даного принципу i направлене їх функціонування. Натомість, адміністративну послугу науковці визначають як забезпечення появи всіх необхідних організаційних умов для здійснення суб'єктами адміністративних правовідносин своїх прав та законних інтересів.

Зробивши узагальнення наукових підходів до розуміння поняття «публічна адміністративна послуга», доцільним стане розкриття сутності адміністративної діяльності з надання публічних послуг. У більшості випадків вчені тлумачать іï як діяльність державного органу виконавчої влади, що спрямована на забезпечення (юридичне оформлення) умов для реалізації прав фізичної або юридичної особи; як результат публічно-владної діяльності, яка здійснювалась за заявою особи.

Треба наголосити на тому, що першоджерелом розкриття змісту адміністративних процедур 3 надання публічних послуг підрозділами Національної поліції $\varepsilon$ Закон України «Про адміністративні послуги» від 06.09.2012 р., згідно з яким «адміністративною послугою є результат здійснення владних по- вноважень суб'єктом надання адміністративних послуг за заявою фізичної або юридичної особи, спрямований на набуття, зміну чи припинення прав та/або обов'язків такої особи відповідно до закону» [3].

Серед іншої важливої інформації, що міститься у цьому законі, також дається чітке розмежування сфери суспільних правовідносин, що пов'язані з наданням адміністративних послуг, суб'єктом яких є, зокрема, і Національна поліція України. В той же час варто підкреслити, що правова регламентація, яку цей закон покликаний здійснювати по відношенню до всіх учасників адміністративних правовідносин, не поширюється на певний перелік традиційних дій, що на постійній основі здійснюють співробітники правоохоронної системи. Такими можна назвати, наприклад, проведення державного нагляду (контролю) чи виконавчого провадження; здійснення дізнання, досудового слідства або оперативнорозшукової діяльності; виконання нотаріальних дій; приведення у дію покарань; надання доступу до публічної інформації; застосування законодавства про захист економічної конкуренції; провадження діяльності, пов’язаної 3 державною таємницею та інші вказані у законі дії адміністративно-правового характеру [4] .

Провівши аналіз адміністративних послуг, які надаються підрозділами Національної поліції, можна дійти логічного висновку про те, що такі послуги умовно можна класифікувати відповідно до їх конкретного змісту. Наприклад: дозвільні (полягають у належному оформленні документів та видачі певних дозволів); ліцензійні (передбачають видачу чи переоформлення ліцензії); реєстраційні послуги; експертні послуги; документального оформлення; оформлення і видавання погоджувальних документів (висновків, довідок).

Також існує поділ публічних адміністративних послуг за юридичними наслідками, що неодмінно настають через здійснення наступних послуг: надання прав (видання дозволів, ліцензій, прийняття екзаменів на право водіння автотранспортних засобів із оформленням реєстраційних документів і документів на право керування транспортними засобами тощо), припинення прав (скасування сертифіката на зброю чи конструктивно схожі із нею вироби, набої, піротехнічні при- 
ладдя та феєрверки; переоформлення зброї за місцем ії обліку з одного власника на іншого; скасування ліцензій, дозволів; переоформлення ліцензї; видання негативних висновків); їх обмеження [5].

Залежно від обсягу адміністративно-процедурних дій з надання публічних послуг їх також можна розділяти на основні та супутні послуги. Зокрема, до основних належать такі, що надаються за заявами з виданням дозвільного, ліцензійного, погоджувального чи іншого документа. У свою чергу, супутні послуги являють собою такі процедури як виготовлення копій документів, ламінування, фотографування, продаж канцелярських товарів, надання банківських послуг тощо. Названі послуги можуть надаватися працівниками Національної поліції України також і в приміщеннях, у яких розміщуються центри з надання адміністративних послуг.

Актуальним питанням є вироблення єдиного наукового підходу до визначення таких дефініцій, як «адміністративні послуги», «поліцейські послуги» та «сервісні послуги», а також проведення розмежування між ними. У контексті цього питання доведеним фактом 6 те, що всі послуги, які надаються Національною поліцією України та іншими розпорядчими суб'єктами виконавчої влади, є адміністративними, оскільки вони пов'язані зі здійсненням владних повноважень органами публічної адміністрації, зокрема, структурними підрозділами Національної поліції.

\section{Висновки}

Отже, до поліцейських послуг слід відносити всі дії, які вказані у Законі України «Про Національну поліцію», як повноваження іiі працівників. Натомість, інші, не визначені вищенаведеним законом послуги, що надаються Національною поліцією, а також спрямовані на створення відповідних умов для безпечної реалізації фізичними та юридичними особами своїх власних прав, свобод і законних інте-ресів за їх заявою, повинні регулюватися Законом України «Про адміністративні послуги» і вважатися сервісними. Наостанок правильним буде звернути увагу на необхідність поступового та неухильного розвитку сфери надання публічних послуг. Задля досягнення найбільшої ефективності та результативнос-

\section{SUMMARY}

The article deals with the peculiarities of the activities of the National Police in providing public services to Ukrainian citizens. Through the analysis of scientific views, the author defines the concepts of "administrative and legal basis", "service state" and "provision of public services" (in the context of the activities of the National Police). It is established that, given the specific status of units of the National Police of Ukraine, their provision of public services to the population has its own characteristic features. Suggestions have been made to improve some of the public service administrative procedures. Particular emphasis is placed on the need to improve the administrative and legal support of the professional activities of police officers. It is proposed to amend the profile legislation in order to increase the efficiency of the activities of the intra-system units that are part of the National Police of Ukraine.

Keywords: national police, public services, service state, structural units, legislative support, legal regulation, administrative law, administrative process, state system.

ті у цій справі державним суб'єктам надання цих послуг (зокрема, і підрозділам Національної поліції) варто втілювати успішні ідеї та практичний досвід розвинених країн, а також працювати над поліпшенням національного законодавства у цій сфері.

\section{Література}

1. Конституція України. Відомості Верховної Ради Украйни. 1996. № 30. Ст. 141.

2. Авер'янов В.Б., Битяк Ю.П. Адміністративне право України. Академічний курс: підручник для студ. юрид. спец. вищих навч. закл.: в 2 т. Т. 1: Загальна частина. Київ: Юридична думка, 2004. 584 с.

3. Про адміністративні послуги: Закон України від 06.09.2012 № 5203-VI Відомості Верховної Ради Украӥни. 2013. № 32. Ст.409.

4. Про затвердження Положення про Міністерство внутрішніх справ України: Постанова Кабінету Міністрів України від 28.10.2015 № 878. Оббіиійний вісник Украӥни. 2015. № 89. Ст. 2972.

5. Тимощук В. П., Кірмач А. В. Оцінка якості адміністративних послуг. Київ: Факт, $2005.88 \mathrm{c}$. 